\title{
Haematological and serum biochemical indices of broiler chickens fed roselle seed meal (Hibiscus sabdariffa l.) As replacement for groundnut cake
}

Onunkwo, D. N., Amaduruonye, W., Nathaniel, J., Ezike, J. C. and Daniel-Igwe, G.

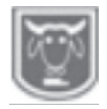

College of Animal Science and Animal Production, Michael Okpara University of Agriculture, Umudike, Abia State Corresponding Author: donunkwo1@gmail.com; 08033388622

\begin{abstract}
This study was carried out to evaluate the haematological and blood biochemical parameters of broiler chickens fed graded levels of Roselle Seed Cake (RSC) diet as replacement for groundnut cake (GNC). Proximate composition of the test diet and experimental diets were conducted to determine their nutrient contents. Four diets were formulated for the broiler chickens. The Diet 1 served as the control diet while diets 2, 3 and 4 contained $8 \%, 16 \%$ and $24 \%$ with Roselle seed cake (RSC) diets respectively as replacement for groundnut cake (GNC). A total of 120, one day-old Ross broiler chicks were randomly allotted to four dietary treatments with four replicates and each treatment consisted of 30 birds in a Completely Randomized Design (CRD). Feed and water were provided for the birds ad libitum. The blood parameters measured are haemoglobin, packed cell volume, red blood cell, white blood cell, heteropils, lymphocytes, monocytes, eosinophils, basophils and band cell. The results from the parameters measured for blood quality showed no significant $(P<0.05)$ differences for haemoglobin level, packed cell volume $(P C V)$, white blood cell $(W B C)$, across the treatments. But the red blood cell (RBC), heterophils and lymphocytes had a significant difference across the dietary treatments and this implies that Roselle seed cake (RSC) inclusions in the diets of the birds had a positive effect on the oxygen carrying capacity, immunity level and antibodies producing capacity of the birds. The blood biochemical parameters measured are total protein, albumin, cholesterol, creatinine, triglycerides, $H D L$ and LDL. The parameters measured showed no significant $(P<0.05)$ differences in total protein (TP), creatinine, high density level (HDL) and low density level (LDL) across dietary treatment while albumin and cholesterol had significant differences $(p>0.05)$ across the dietary treatments. RSC can replace GNC at 16\% dietary inclusion levels.
\end{abstract}

Keywords: Haematology, Serum biochemical, Roselle seed meal, Groundnut cake

\section{Introduction}

The poultry industry in Nigeria, in the last decade, has been greatly affected by high cost of feed (Ogbuewu et al, 2010). The provision of feed alone has been reported to account for $60-80 \%$ of the total cost in most livestock production in developing countries such as Nigeria (Igboeli, 2000) and this emphasize the interest to develop local feedstuffs. Protein is a very important nutrient that is responsible for growth and its deficiency leads to growth depression. Proteins are used in the construction of body tissues such as muscles, nerves, cartilage, skin, feathers, beak, and so on.
All animals require protein for growth, reproduction and production depending on the age, productivity of the animal and their environment (Olomu, 1995). The conventional protein feedstuffs for poultry such as soya bean meal (SBM), groundnut cake (GNC) and fish meal (FM) are scarce and expensive because they are competed for by humans as food and other industrial uses. The development of alternative protein feedstuffs in animal diets will therefore continue to be a necessity in developing countries. In view of this, there isincreased interest by Nigerian livestock farmers to harness unconventional feed 


\section{Haematological and serum biochemical indices of broiler chickens}

ingredients such as Roselle seed meal.Roselle (Hibiscus sabdariffa L.) belongs to the malvaceae family and forms a popular vegetable in Indonesia, India and many tropical regions (Tindal, 1986). It is now widely grown in the North Eastern and middle belt regions of Nigeria (Akanya et al., 1997) mainly for its calyxes used for the preparation of a local drink but the leaves are also used for soup and as pot herb (Adigun, 2003). The leaves are used as vegetable and the floral parts in the preparation of "Zobo", a local drink. The stem provides fibre and the seeds are eaten by scavenging poultry (Phillips, 1997).The seed of Hibiscus sandariff is said to have high protein value and it is on account of its protein content that it is well priced for human consumption. They also contain high amount of minerals such as calcium, magnesium and phosphorus. The seeds from Nigeria are reported to contain about $35.90 \%$ crude protein, $10.14 \%$ ether extract, $10.09 \%$ ash and $15-17 \%$ crude fibre (Dashak and Nwanegbo, 2002). The use of blood examination as a way of assessing the health status of animals plays a vital role in physiological, nutritional and pathological status of such animal (Muhammad et al., 2000). Haematology has been defined as the study of blood and an important part of clinical pathology as well as diagnostic process (Lutz and Pryluski, 2008). Haematology includes not only the examination of the cellular and fluid portions of blood, but also includes a study of the tissues that form, store and circulate blood cells. However, the serum is the component that is neither a blood cell nor a clotting factor. It is the part of blood that is like water and that contains substances (called antibodies) that fight disease. Serum includes all proteins not used in blood clotting and all the electrolytes, antibodies, antigens, hormones and any exogenous substances (Martin, 2007). The result of haematology and serum analysis is usually used to assess the health status of an animal. Haematological and serum parameters have been observed as good indicators of the physiological status of animal and their changes are important in assessing the response of such animal to various physiological situations (Khan and Zafar, 2005). This study was carried out to determine the effects of Roselle seed cake meal on haematological and serum biochemical profile of broiler chickens.

\section{Materials and methods}

The experiment was carried out at the Poultry Unit of Teaching and Research Farm of Michael Okpara University of Agriculture, Umudike, Abia State, Nigeria. Umudike is located within Latitude $5^{\circ} 28^{\prime}$ North, longitude $7^{\circ} 32^{\prime}$ East and on an altitude of $122 \mathrm{~m}$ above sea level. The area falls within the Tropical Rainforest zone. Annual rainfall averages $2177 \mathrm{~mm}$. The monthly ambient temperature ranges between $20 \mathrm{oC}$ and $36 \mathrm{oC}$, and relative humidity between 50 and $59 \%$, depending on season (NRCRI, 2017). The experimental materials; maize, Roselle seeds, soya bean meal, etc were procured from a local market in Umuahia, Abia State. Samples of the Roselle seedcake and experimental diets were taken to the Animal Science Biochemical Laboratory of Michael Okpara University of Agriculture, Umudike, Abia State, Nigeria for proximate analysis using the methods described by A.O.A.C (2005). The analysis was done to obtain the nutrient composition (Dry matter, Ash, ether extract, crude protein, crude fibre and nitrogen free extract) of the experimental diet. The metabolizable energy was determined using the Janssen formula (Janssen, 1989). Four diets isonitrogenous and isocaloric diets $(22.62$ $\% \mathrm{CP} ; 2959 \mathrm{kcal} / \mathrm{kg} \mathrm{ME}$ ) were formulated for the broiler chickens as follows: Diet 1 : 
$0 \%$ of Roselle seedcake in the diet (control), Diet 2: 8\% level of Roselle seed cake in the diet, Diet 3: 16\% level of
Roselle seed cake in the diet and Diet 4: $24 \%$ level of Roselle seed cake in the diet. Gross composition of the experimental straight diet is presented in Tables 1.

Table 1: Gross Composition of Experimental straight diet with Roselle Seed Cake as Replacement for Groundnut cake

\begin{tabular}{llllll}
\hline & \multicolumn{7}{c}{ Levels of Roselle Seed Cake (RSC) Inclusion (\%) } \\
Ingredient (\%) & $\mathbf{0}$ & $\mathbf{2 5}$ & $\mathbf{5 0}$ & $\mathbf{7 5}$ & $\mathbf{1 0 0}$ \\
\hline Maize & 58.05 & 59.45 & 56.55 & 53.85 & 50.85 \\
Roselle seedcake & 0.00 & 8.00 & 16.00 & 24.00 & 32.00 \\
Soyabean cake & 10.00 & 10.00 & 10.00 & 10.00 & 10.00 \\
Groundnut cake & 24.00 & 15.40 & 10.30 & 5.00 & 0.00 \\
Blood meal & 3.00 & 3.00 & 3.00 & 3.00 & 3.00 \\
Bone meal & 3.00 & 3.00 & 3.00 & 3.00 & 3.00 \\
Limestone & 0.30 & 0.30 & 0.30 & 0.30 & 0.30 \\
Common salt & 0.25 & 0.25 & 0.25 & 0.25 & 0.25 \\
Methionine & 0.25 & 0.25 & 0.25 & 0.25 & 0.25 \\
Lysine & 0.10 & 0.10 & 0.10 & 0.10 & 0.10 \\
*Vitamin premix & 0.25 & 0.25 & 0.25 & 0.25 & 0.25 \\
Total & 100 & 100 & 100 & 100 & 100 \\
Calculated Analysis & & & & \\
ME (Kcal/kg) & 2959.00 & 2959.00 & 2965.00 & 2945.00 & 2916.00 \\
Crude protein (\%) & 23.62 & 22.62 & 22.65 & 22.62 & 22.69 \\
\hline
\end{tabular}

One hundred and twenty (120) day old Ross broiler chicks were purchased from a reputable farm in Ibadan and were used for the starter and finisher phases. The broiler chicks on arrival were counted and were given a common ration for one day and allowed to adapt to the environment. Their initial average weight was recorded and the chicks were randomly distributed into four treatment groups of 30 chicks each with four replicates of 15 chicks per pen in a Completely Randomized Design (CRD). Each group was assigned to the four experimental diets and they were all subjected to the same management practices all through the period of the experiment. The birds were given lasota Intra ocular (I.O) vaccine on arrival and vitalyte was added to their water to reduce stress. They were given their first dose of gumboro at 7 days old, first dose of lasota at 14 days old while second dose of gumboro and second dose of lasota were administered at 21 days and 28 days old respectively. The birds were also treated against coccidiosis orally at 3 weeks of age. The birds were assigned to four dietary treatments where RSC was included at 0,8 , 16 and $24 \%$ respectively. The $0 \%$ represents the control group without Roselle seed cake in their diets while others are fed diets with inclusion of Roselle seed cake in their diet. Feed and water were provided ad libitum throughout the study period. At the end of the experiment, 1.5 millilitres of blood were collected from the wing vein of each bird with disposable $2 \mathrm{ml}$ syringes and needle set. Three birds per replicate making a total of nine birds per treatment were randomly selected. Blood samples were collected into labelled bottles containing Ethylene Diamine Tetra acetic Acid (EDTA) and taken to the nutrition and biochemical laboratory for determination of haematological parameters. The samples were assayed for: Packed cell volume (PCV), haemoglobin content $(\mathrm{Hb})$, white blood cell (WBC), red blood cell (RBC) and 


\section{Haematological and serum biochemical indices of broiler chickens}

differential blood count (heterophils, lymphocytes, monocytes, eosinophils, basophils and band cell).

\section{Statistical analysis}

The data obtained from the study were analyzed using One-way ANOVA. The General Linear Model procedure of Statistical Analysis System (SAS, 2002) was used and the mean was separated using Dunnet because the control diet was used to compare with other treatments (Dunnet, 1964).

\section{Results and discussion}

According to the proximate composition of Roselle seed cake presented in Table 2, the dry matter content was $95.15 \%$, crude protein $32.45 \%$, crude fiber $4.25 \%$, ash $6.25 \%$, ether extract $10.05 \%$ and nitrogen free extract content was $50.05 \%$. Ether extract value of $10.05 \%$ was lower than the value of $15.4 \%$ reported by some authors. The metabolizable energy value of $3059.64 \mathrm{kcal} / \mathrm{kg}$ agreed with the range of $2880-3500 \mathrm{kcal} / \mathrm{kg}$ reported by various authors. The variations in values obtained and reported by various persons could be as a result of different sources of Roselle seed cake, differences in processing methods and storage conditions. The values obtained for haemoglobin $(11.56-12.37 \mathrm{~g} / \mathrm{dl})$ for broiler chickens $0 \%$ (control) diet to $24 \%$ diet group fell within the normal range values $(8.00-13.00 \mathrm{~g} / \mathrm{dl})$ for domestic chickens as shown in Table 3. This signifies that the birds had good aerobic capacity and were not aneamic. The packed cell volume values obtained amongst the treatments are not significantly different $(\mathrm{p}<0.05)$ except for T2 $(8 \%)$ which is higher with value $37.27 \%$ and show a significant difference from others. The red blood cells values obtained from T4 (24\%) and T2 (8\%) diets agreed with the average values of RBC $(2.5-4.5 \mathrm{~mm} 3)$ while that of T3 $(16 \%)$ and T1 $(0 \%)$ are a bit higher. This implies that birds under T3 and T1 diets had higher oxygen carrying capacity but none of the birds had depressed bone marrow. There is no significant difference $(\mathrm{p}<0.5)$ in the white blood cell (WBC) values amongst the dietary treatments. This showed that the birds WBC produced antibodies which protected the birds from infectious agents. The Heterophils were not significantly different $(p<0.05)$ within the dietary treatments except for T3 (16\%) diet which is higher and significantly different $(\mathrm{p}$ $>0.05$ ). This implies that birds under T3 diets had higher immunity to infections and bacteria than birds in other dietary treatments since high level of heterophil prevents infections. The lymphocyte values obtained from T2 $(8 \%)$, T3 (16\%) and T4 (24\%) diets; 51.43-53.16\%showed significantly different $(p>0.05)$ from that of T1 (control) diet; 50.02. They all agreed with the average value which is around 20$55 \%$ but birds under the control diet produced lesser antibodies than birds under $8 \%-24 \%$ dietary treatments. The differential counts like Eosinophil, Monocytes, Basophils and Band cells were not significantly difference $(p<0.05)$ from each other across the dietary treatments.

Table 2: Proximate composition and energy value of Roselle seed cake

\begin{tabular}{ll}
\hline Parameters & $\mathbf{\%}$ \\
\hline Crude protein & 32.45 \\
Crude fibre & 4.25 \\
Dry matter & 95.15 \\
Ash & 6.25 \\
Ether extract & 10.05 \\
Nitrogen free extract & 50.05 \\
Metabolizable energy $(\mathrm{kcak} / \mathrm{kg})$ & 3059.64 \\
\hline
\end{tabular}


Onunkwo, Amaduruonye, Nathaniel, Ezike and Daniel-Igwe

Table 3: Haematological indices of broiler chickens fed graded levels of Roselle seed cake as replacement for groundnut cake

\begin{tabular}{lllll}
\hline Parameters & T1 & T2 & T3 & T4 \\
\hline Hb $(\mathrm{g} / \mathrm{dl})$ & $11.56^{\mathrm{b}}$ & $12.37^{\mathrm{a}}$ & $11.06^{\mathrm{c}}$ & $11.55^{\mathrm{b}}$ \\
PCV $(\%)$ & $35.40^{\mathrm{b}}$ & $37.27^{\mathrm{a}}$ & $33.57^{\mathrm{d}}$ & $35.02^{\mathrm{c}}$ \\
$\mathrm{RBC}\left(\times 10^{6} / \mathrm{dl}\right)$ & $4.60^{\mathrm{a}}$ & $4.10^{\mathrm{b}}$ & $4.47^{\mathrm{a}}$ & $3.99^{\mathrm{b}}$ \\
$\mathrm{WBC}\left(\times 10^{3} / \mathrm{ml}\right)$ & $4.44^{\mathrm{a}}$ & $4.33^{\mathrm{a}}$ & $4.08^{\mathrm{b}}$ & $4.27^{\mathrm{ab}}$ \\
Heterophils $(\%)$ & $14.31^{\mathrm{c}}$ & $14.32^{\mathrm{c}}$ & $16.24^{\mathrm{a}}$ & $15.77^{\mathrm{b}}$ \\
Lymphocytes(\%) & $50.02^{\mathrm{c}}$ & $53.16^{\mathrm{a}}$ & $51.43^{\mathrm{b}}$ & $53.04^{\mathrm{a}}$ \\
Eosinophils (\%) & 0.00 & 0.00 & 0.00 & 0.00 \\
Monocytes (\%) & 0.00 & 0.00 & 0.00 & 0.00 \\
Basophil (\%) & 0.00 & 0.00 & 0.00 & 0.00 \\
Band cell (\%) & $0.44^{\mathrm{a}}$ & $0.00^{\mathrm{b}}$ & $0.00^{\mathrm{b}}$ & $0.00^{\mathrm{b}}$ \\
\hline \multicolumn{2}{l}{ Means within rows with same superscript indicate significant differences with respect to different items tested at $\mathrm{p}<0.05$}
\end{tabular}

There were no significant differences $(\mathrm{p}<0.05)$ in the total protein as shown in Table 4. The values obtained from the dietary treatments $(2.75-3.01 \mathrm{~g} / \mathrm{dl})$ agrees with the average total protein value (2.5$5.5 \mathrm{~g} / \mathrm{dl}$ ) and this shows that the birds growth and body were proper. There was significant differences $(p>0.05)$ in albumin and cholesterol values of the different dietary treatments. This indicates that Roselle seed cake had an effect on the protein, cholesterol level and health status of the birds. The creatinine values obtained $(0.44-0.52 \mathrm{mg} / \mathrm{dl})$ fell within the range values $(0.20-0.5 \mathrm{mg} / \mathrm{dl})$ and this signifies that roselle seed cake did not have any detrimental effect on the kidney function of the birds because feeds were properly utilized by the birds. There was significant difference $(p>0.5)$ in tryglyceride value between the different dietary treatments with $24 \%$ dietary treatment being the highest amongst others. High density lipoprotein (HDL) and low density lipoprotein (LDL) is a combination of lipids and proteins. The higher the lipoprotein value, the better because it lowers the risk of coronary artery disease.

Table 4: Blood biochemical parameters of broiler chickens fed graded levels of Roselle seed cake as replacement for groundnut cake

\begin{tabular}{lllll}
\hline Parameters & T1 & T2 & T3 & T4 \\
\hline Total Protein $(\mathrm{g} / \mathrm{dl})$ & $3.01^{\mathrm{a}}$ & $2.90^{\mathrm{a}}$ & $2.99^{\mathrm{a}}$ & $2.75^{\mathrm{b}}$ \\
Albumin $(\mathrm{mg} / \mathrm{dl})$ & $42.31^{\mathrm{b}}$ & $35.31^{\mathrm{c}}$ & $43.31^{\mathrm{a}}$ & $31.31^{\mathrm{d}}$ \\
Cholesterol $(\mathrm{mg} / \mathrm{dl})$ & $111.21^{\mathrm{d}}$ & $113.53^{\mathrm{c}}$ & $115.62^{\mathrm{b}}$ & $116.12^{\mathrm{a}}$ \\
Creatinine $(\mathrm{mg} / \mathrm{dl})$ & $0.52^{\mathrm{a}}$ & $0.45^{\mathrm{b}}$ & $0.52^{\mathrm{a}}$ & $0.44^{\mathrm{b}}$ \\
Triglycerides $(\mathrm{g} / \mathrm{dl})$ & $70.64^{\mathrm{c}}$ & $71.51^{\mathrm{b}}$ & $71.42^{\mathrm{b}}$ & $73.44^{\mathrm{a}}$ \\
HDL $(\mathrm{mg} / \mathrm{dl})$ & $70.64^{\mathrm{c}}$ & 71.51 & $71.42^{\mathrm{b}}$ & $73.44^{\mathrm{a}}$ \\
LDL $(\mathrm{mg} / \mathrm{dl})$ & $33.55^{\mathrm{a}}$ & $33.27^{\mathrm{b}}$ & $32.3^{\mathrm{c}}$ & $32.347^{\mathrm{c}}$ \\
\hline
\end{tabular}

Means within rows with same superscript indicate significant differences with respect to different items tested at $\mathrm{p}<0.05$. HDL $=\mathrm{High}$ density lipoprotein, $\mathrm{LDL}=$ Low density lipoprotein

\section{Conclusion}

Based on the findings from the study, it was concluded that Roselle seed cake (RSC) as an alternative feedstuff can replace groundnut cake (GNC) at 16\% dietary roselle seed cake inclusion levels and incorporated in the diet of broiler chickens. Inclusion of RSC in the diets of broiler chickens did not have adverse effect on the haematology. Feeding RSC to broiler chickens do not have any adverse effect on their blood biochemical indices. 
References

Akanya, H. O., Oyeleke, S. B., Jigam, A. A. and Lawal, F. F. 1997. Analysis of sorrel drink Nigeria. J. Biochemical.12: 77-79

Adigun, J. A. 2003. Effect of intra- row spacing and weed control on growth and yield of Roselle (Hibiscus sabdariffa) in southwest Nigeria.Asset series A.3(2):91-98

A.O.A.C 2005. Official method of analysis of the association of official analytical chemicals. W. Horwitz ( Edn) 18thedition, Washington D.C.

Dashak, D. A. and Nwanegbo, V. 2002. "Chemical composition of the seeds and catalyzes of Hibiscus sabdariffa grown in Jos North Local Government Area of Plateau State" Journal of Natural Sciences, 5: 32-34

Duke, Y. A. 1985. Handbook of medicinal herbs. $13^{\text {th }}$ ed. Living Stone Group Ltd., Edinburgh, Pp: 228 229

Dike, M. C. 1987. Insect pests of kenaf and roselle in the Zaria area of northern Nigeria. A paper presented at the 17th Annual Conference of the Nigerian Society for Plant Protection. University of Nigeria, Nsukka In: Okosun, L.A. (2000). Effect of plant density, sowing date and fertilizer on the growth and yield of roselle (Hibiscus sabdariffaL.) in the sudan savannah. Ph.d thesis presented to the postgraduate school, U s m a n Danfodio University, Sokoto, Nigeria. Pp: 186.

Igboeli, G. 2000. Animal production and Agriculture in the new millennium. B o o k of proc. $25^{\mathrm{th}}$ Ann.NSAP. Conf., pp 1-3

Janssen, W. M. M. A. 1989. European tables of energy values for poultry feedstuffs. $3 \mathrm{rd}$ e d. Beekbergen Netherlands (Spelderholt Centre for Poultry Research and Information Services). Pp: 84

Khan, T. A. and Zadar, F. 2005. Hematological study in response to varying doses of estrogen in broiler chicken. International journal of poultry science. 10:748751

Lutz, C. and Pryztulski, K. 2008. Nutrition and diet therapy. 4th Ed. Jaypee Brothers Medical Publishers New Delhi. Pp312

Mahadevan, N., Shivali A., and Kamboj, P. 2009. Hibiscus sabdariffa Linn. An overview of Natural Product Radiance 8(1): 77-83

Malik, C. P. and Srivastava, A. K. 1982. Textbook of Plant Physiology. Ludhiana, New Delhi.

Martin, L. P. 2007. The moringa tree. Echo. North Fort Myers, FL 33917 , U S A. Avail a ble at: http://www.echonet.org

Muhammad, N. O., Adeyina, A. O. and Peters, O. M. 2000. Nutritional evaluation of fungi treated cocoa bean shell. Nigerian journal. Pure and Appl.sci.,5:1059-1064

N.R.C. 1994. National Research Council. Nutrient requirements of poultry 9th Rev. Edn. $\quad \mathrm{N}$ a $\mathrm{t}$ i o $\mathrm{n}$ a 1 Academy Press, Washington, D.C.

Odigie, I.P., Ettarh, R.R. and Adigun, S.A. 2003. Chronic administration of aqueous extract of Hibiscus sabdariffa attenuates hypertension and reverses cardiac hypertrophy in $2 \mathrm{k} 1 \mathrm{c}$ hypertensive rats. J. Ethnipharmacol., 86:181-185

Ogbuewu, I. P. 2010. Physiological responses of rabbits fed graded levels of Neem ( Azadirachta indica) leaf meal. M.sc Thesis, 
Federal University of Technology, Owerri, Nigeria. Pp: 35

Olomu, J. M. 1995. Monogastric animal nutrition, principles and practice. Jackem Publications, Benin City, Nigeria. Pp: 69-104

Oluremi, O. I. A. and Sridhar, M. K. C. 2004. Effects of domestic effluent utilization on the blood characteristics of grower pullets. Nigerian Journal of Animal Production, 31(2):200-206
Philips, T. A. 1997. An agricultural textbook. Long man group limited, London, pp:89-101SAS 2002. Statistical Analysis System Institute. Users Guide Version 9 for Windows. Cary North Carolina USA.

Tindal, H. D. 1986. Vegetable in the tropics. Macmillan End. 1td. Hampshire. pp:268-269.

Received: $14^{\text {th }}$ September, 2018 Accepted: $21^{\text {st }}$ December, 2018 